\title{
PEDAGOGICAL EDUCATION IN RUSSIA: CHALLENGES, PROSPECTS, AND QUALITY ASSURANCE
}

\author{
Irina Kulikovskaya ${ }^{1}$, Anna Andrienko ${ }^{2}$
}

\begin{abstract}
The development of education and science is a priority for Russian state policy. Global trends define the main goals of the Russian higher school modernization. However, these also identify the need to overcome a number of contradictions in Russia's national higher-education system. Pedagogical, or teacher-training, education is of special importance in the development of the entire educational system in the country. Quality education at all steps - preschool, primary, secondary (general and professional) and higher - depends mainly on the quality of pedagogical education. The modern market of educational services recognizes high quality of education and competences of students as the only advantage point for an academic institution over its competitors. Quality is the only universal commodity in the world market that increases the value of all other goods and services. The authors refer to the category of quality management in relation to higher pedagogical education, and describe the key principles of the system of quality assurance applied at Southern Federal University.
\end{abstract}

UDC Classification: 378, DOI: http://dx.doi.org/10.12955/cbup.v3.621

Higher education, pedagogical education, challenges, quality assurance, Russia

\section{Introduction}

In many respects today, the quality of human resources defines the competitiveness of the state. Developing public intelligence guarantees the stability and prosperity of a country. Understanding the indisputable value of human potential makes it possible to define education as the leading mechanism for reproducing culture, the source of new knowledge and human resources of high quality. As Cortese (2003, p.17) notes "Higher education institutions bear a profound, moral responsibility to increase the awareness, knowledge, skills, and values needed to create a just and sustainable future. Higher education often plays a critical but often overlooked role in making this vision a reality. It prepares most of the professionals who develop, lead, manage, teach, work in, and influence society's institutions".

This approach explains the government's steady interest in various issues of education, especially at the tertiary level. The development of education and science is a priority for Russian state policy. Global trends define the main goals of modernizing Russia's higher education system on the one hand, and a need to overcome several contradictions of this system on the other.

\section{General World Trends in Higher Education}

The report prepared for the UNESCO 2009 World Conference on higher education, depicted an academic revolution because of the changes occurring in the modern world of education (Education International, 2009). These have occurred over the past half century with unprecedented transformations in scope and diversity. Such dramatic changes inevitably challenge the system of well-established institutions, and set new standards for governments. We provide a brief review of the global trends in higher education. The UNESCO 2009 Report outlined these trends (Altbach, Reisberg, \& Rumbley, 2009) with the following key issues:

- internationalization at regional and international level;

- increase of autonomy and academic freedom of higher educational institutions along with their rigid accountability;

\footnotetext{
${ }^{1}$ Irina Kulikovskaya, Doctor of Pedagogical Sciences, professor, head of Preschool Education Department, Academy of Psychology and Pedagogy of Southern Federal University, Russia, d700074@ yandex.ru

${ }^{2}$ Anna Andrienko, Candidate of Philological Sciences (PhD equivalent), associate professor of English Philology Department of Southern Federal University, ann-andrienko@mail.ru
} 
- serious transformation and updating of the systems of higher education in order to increase their flexibility, to meet consumers' expectations and create strong bonds with other steps and forms of education, especially postsecondary education;

- continuous adaptation of educational programs to future requirements, and improvement of higher education content in terms of adequacy and relevance;

- transition of higher education to the paradigm "life-long education";

- granting students an opportunity to make a choice about when to begin and when to stop receiving higher education;

- strategy of higher education development, based on social partnership, and connection of higher education with the world of business;

- achieving good balance between the cognitive knowledge of academic subjects and mastering crucial skills in the sphere of communication, and creative and critical analysis;

- focus on interdisciplinary and trans-disciplinary educational programs;

- introduction of modular training programs as a new organizational framework for training and teaching;

- increasing student mobility; and

- the idea that academic staff are at the heart of the academic mission.

All the above-mentioned trends characterize the world of today's higher education and require special attention from academic authorities globally, and especially in Russia.

\section{Higher education in Russia - Challenges and shortcomings}

The integration of Russia into the world's education space assumes the creation of new models to allow tertiary institutions to follow global trends. However, numerous unresolved problems restrain many aspects of such reforms. Russian researchers Frolov (2014), Kulikovskaya \& Mareev (2009), and Ardashkin (2014) emphasize the specific strain placed on most academic systems of Russia, with the transitioning of Russian education, by identifying the following key issues:

- insufficient flexibility of educational programs, and poor response to real requirements of labor market and business;

- mismatch of the structure of educational organizations, and specialty requirements of the economy and social sphere, and an overwhelming increase in the private higher-educational institutes, which frequently provide poor quality education;

- lack of effective control and assessment systems for estimating the quality of university graduates' knowledge and skills;

- lower professional level of teaching staff and the professoriate;

- obsolete material resources and teaching equipment at most higher educational institutions, with no likelihood of updates; and

- inequality among higher educational institutions in terms of excellence and quality.

Higher pedagogical education in modern Russia shares all the problems of higher education generally, but with several specific features. The reform of pedagogical education has been the focus of Russian officials and researchers since the 1990s. However, several conflicting trends influence the current development of pedagogical education in Russia. For instance, pedagogical, or teacher-training, institutions have become scientific and methodical centers of regional academic importance. They received university status, verifying their importance in providing fundamental knowledge. However, 
these universities introduced a large array of general scientific and humanitarian disciplines in place of purely pedagogical subjects. It may seem ridiculous, but many Russian pedagogical universities tried to shift from narrow pedagogical specialization to non-pedagogical specialties for preparing economists, lawyers, and interpreters. As a result, we witnessed the transformation of pedagogical institutions into classical humanitarian colleges and universities. Economic reasons would have prompted these transformations, which clearly positioned the classical university in a much wider market sector for attracting large budgetary allocations.

A significant number of officials support the idea of "folding" higher pedagogical institutions. Impartiality and radicalism, both at the same time, conclude that higher pedagogical education in Russia is superfluous, and that teachers with specialized professional preparation are redundant in the modern school system. They believe that classical universities, institutes of culture, and other tertiary institutions can succeed in preparing contemporary teachers. There is an opinion among academic authorities that by increasing the pedagogical component of non-specialized institutions, they meet the requisite for training suitable teachers. The demographic recession, and surplus of the people with degrees in teaching, supports the thinking that the country has no need for advanced teacher training institutions. Moreover, the elimination of these specialized institutions will release additional budgetary funding to support the pedagogical components of non-specialized higher educational institutions.

The above said position appears radical for the following reasons. We believe pedagogical education is the "neural center" of all modern education. It provides huge social and cultural opportunities. In terms of scientific and methodical content, it embraces all levels of Russian education: preschool, primary, secondary, professional, and postgraduate. Pedagogy personifies all systems of national education, and predicts and forecasts the future of education. Only pedagogical institutions purposefully train real experts for teaching. The professional competence of these experts depends on a pedagogical culture, while in other higher educational institutions there is the tendency to ignore the problems of graduates' inner development. Supporters of the idea of preparing teachers in classical universities are convinced that it is enough to train experts to know their subject well. They consider an intelligent person with a high level of knowledge is fully able to teach successfully. However, it becomes obvious today, that all attempts to destroy the system of higher pedagogical education for the sake of modernization, reconstruction, and optimization, are not just contradictory to world trends, but also undermine the education principles of the state. The modern schools need teachers with high levels of knowledge and intelligence, but desperately need those with well-rounded and specialized qualifications

New global tendencies of education create a new kind of school; a humanistic, variable school of pedagogical creativity that focuses on developing the personal potential and spiritual culture of pupils. Pedagogical education has to prepare graduates with new skills, a broad knowledge base, and a range of competencies to enter a more complex and interdependent world of modern school. Modern teachers have to work under conditions that their predecessors could not even imagine. These are the marketing of educational services, diversifying and globalization of education, and a closer alignment with science, business, and religion. These conditions require highly qualified specialists in the modern school. Today's situation requires a schoolteacher beyond that of simply being a means of transferring subjectfocused knowledge.

In this respect, we believe that educators in Russia should concentrate on creating a standard regulatory base for teacher training, develop the new concepts of pedagogical education, and introduce modern educational technologies into academia, rather than separate and disregard pedagogy altogether. The value of education at all levels depends largely on the quality of pedagogical education. This relates to preschool, primary, secondary (general and professional), and higher. Pedagogical education is the original professional sphere, where a graduate could qualify for a successful career in teaching and include secondary or additional qualifications to their major. 


\section{Key principles of the quality management system at Southern Federal University}

Considering the above-mentioned challenges, we could conclude that Russia feels the urgent need to develop and improve the system of pedagogical education using the best traditions, on one hand, and contemporary reality, on the other. The search for the optimal way of modernizing the sphere of higher pedagogical education has led to the emergence of new Federal Universities, formed from several merges. The nine Federal Universities in Russia include either pedagogical or teacher-training departments as the major components. The Southern Federal University (SFedU) is one of the nine. It was founded in 2006, with the merger of classical, technical, and pedagogical universities, and the Institute of Architecture and Arts. The foundation of the SFedU related to the modernization of higher education in Russia, in particular, the formation of academic, scientific, and innovative complexes from Russian higher educational institutions. These campuses involve complicated infrastructure, which includes centers for marketing, commerce, technology, and research and development. Transforming universities into centers for the development of science, education, production, and culture allows them to lead the way in national innovation.

The SFedU is now trying to establish a footing in the global higher education stage, to develop a reputation as a modern and competitive higher educational institution in the world market of work and knowledge. The modern market of educational services recognizes the main advantage of an academic institution over its competitors is its quality of education and knowledge base. Quality is the only universal product in the world market that can increase the value of all other goods and services. Institutions capable of sustaining the fiercest competition dominate the world market in terms of quality. The nation-wide value of SFedU refers neither to volume of the budgetary and surplus funds nor to the number of eminent scientists and teaching professoriate. It relates to achieving quality of education, science, and production that meets international standards or above.

In the context of scientific and technical progress and the contemporary information revolution, the quality of education gains increasing value. We share the holistic understanding of quality in education, presented by UNICEF (2000). The development of formal quality assurance is one of the most significant trends to affect higher education systems during the past few decades. According to Maguad \& Krone (2012), there are several reasons why the theory of quality management applies to higher education. One reason is that quality management not only conforms with but also supports the existence of educational reforms. Additionally, "quality management is a paradigm capable of integrating several diverse higher education reform movements (e.g. accreditation or input-based approach and outcomes assessment approach) so that these attempts at reform can make their optimal contribution" (p.13).

Quality, as a priority of the state, includes different dimensions: quality of work, quality of production, quality of management, quality of life, social relations, and similar associations. To achieve high quality in education, it is first necessary, to define the object of quality management. At SFedU we believe that the real educational existential measurement is carried out in the system of "teacher - student". University teachers are the only persons able to raise or lower the quality of education directly, and Southern Federal University (SFedU) authorities share this assumption. The activity of other participants (administrative, scientific, and economic) has indirect effect on the quality of education provided by a teacher. For this reason, the main object of quality management in this higher educational establishment refers to the system of "teacher - student". This system adjusts and regulates three key parameters: 1) the responsibility of the teacher and the student to achieve academic results (their motivation for work); 2) content of education; and 3) education technologies. The central point is the understanding that quality cannot be bought in the market and is a commodity within the institution boundaries (Lamanauskas, 2008). 
The quality of education at SFedU does not represent a certain number of educational system indicators, each with a threshold level. What is education? What is the quality of education that remains after omitting the external and quantitatively represented features? In this, we refer to features such as the condition of university facilities, good library stock, space allocated per student, material and financial assets, and many other, undoubtedly important indicators. Academic processes in higher education institutions consist of every-day situations, like interactions between teachers and students. Various necessities in organizing education, apart from simple academic situations, include buildings, facilities, equipment, material and financial resources, systems of administrative management, and similar features. Quality management of education is the system regulating the nature of relationships between teachers and students. The leading role in organizing educational processes, and the management of an academic situation, belongs to members of the teaching staff. Therefore, managing the teacher's (or professor's) attitude to the professional activity also defines quality management.

The quality of educational management depends on teachers, which are the main component, or leading party, of educational processes. The teacher brings to life the content of the education, and the technical means and technologies of training. The high personal and professional culture of teachers encourages adaptations in the educational process that relate to personal traits, and personal and professional development of students. The teacher is capable of changing the bar of academic excellence, since they have immediate access to the direct subject of education quality management, whereas other participants of education quality management (heads of institutions and their divisions, scientific employees, administrative staff, and parents) can only indirectly affect the quality of education, through the teacher. All educational systems have a certain set of the conditions, intended to increase overall performance of the teacher, and make improvements. There is always a teacher between management of educational system and education quality management. Their consciousness, culture, professionalism, responsibility, motivation, and dedication to work largely determine how much quality of education will conform to the requirements of external management and personal requirements of students.

The teacher is the most qualified expert in quality management owing to their special place in education. In real time, the teacher sees the results of their own activity, compares these with goals, and makes the necessary changes in the course of teaching. Professional competence and rich personal experience allow the teacher to estimate fully the quality of both their work, and the work of colleagues. All other experts (administrators, members of special boards and committees, and the like) deal primarily with formalized indicators of academic process.

The quality management system applied at SFedU assists with the interaction of students, higher educational institutions, and employer, by focusing on shaping the key competencies of graduates. Hutmacher (1996) mentions five groups of the key competencies of special significance, defined by the Council of Europe. In this, the greater dynamics of modern business demands graduates with a flawless professional qualification, and with sound organizational and administrative skills. This means skills to be able to find that necessary information in a timely fashion, to plan and set priorities, and to optimize production by applying the most effective administrative approaches. When employers select applicants for professional jobs, they pay special attention to the professional competencies, but also to personal, social, and administrative skills of the applicant. Hence, a competence-based approach would enable higher educational establishments to prepare candidates for future careers.

\section{Conclusion}

The system of education management at SFedU provides conditions necessary for high quality achievements of teachers and students. The modern market of educational services recognizes the quality of education and competences of students from an academic institution is the single advantage point the institution has over another. The system "teacher - students - employer" as the object of quality 
management has proven to be an effective means of quality assurance. After further approbation, this system will be ready to solve the task set by the Russian President to prepare competent professionals for the country. Then, all will be on an upward learning curve.

\section{References}

Altbach, P. G., Reisberg, L., \& Rumbley, L. E. (2009). Trends in global higher education: tracking an academic revolution. A report prepared for the UNESCO 2009 World Conference on higher education. Executive summary. Paris: UNESCO.

Ardashkin, I. B. (2014). Philosophy of education as a social development factor: World trends and prospects for Russia. International Conference on Research Paradigms Transformation in Social Sciences 2014. Procedia - Social and Behevioral Sciences, 166(2015), 277-286.

Cortese, A. D. (2003). The critical role of higher education on creating a sustainable future. Planning for higher education, $31(3), 15-22$

Frolov, A. S. (2014). Strategicheskiye problemy razvitiya vysshego obrazovaniya v sovremennoy rossii [Strategic problems of development of higher education in modern Russia]. Journal of Altay Academy of Economics and Law, 3, 130-135.

Hutmacher, W. (1996). Key competencies for Europe. Report of the Symposium Berne, Switzezland 27-30 March, 1996. A secondary education for Europe Project. Strasbourg, France: Council for Cultural Cooperation. Retreived from http://files.eric.ed.gov/fulltext/ED407717.pdf.

Kulikovskaya, I. E., \& Mareev, V. I. (2009). Strategicheskoye upravleniye kachestvom obrazovaniya v Yuzhnom federal'nom universitete [Strategic management of pedagogical education quality in Southern Federal University]. News of Southern Federal University. Pedagogical Sciences, 12, 27-42.

Lamanauskas, V. (2008). Quality of higher education: ideals and reality. Problems of education in the 21 st Century, 7, 5.

Maguad, B. A., \& Krone, R. M. (2012). Managing for quality in higher education: A system's perspective. An instructional text for teaching the quality sciences. Retrieved September 10, 2014 from: bookboon.com.

Education International. (2009, July). Statement to the UNESCO World Conference on higher education. Educators committed to quality higher education in the coming decade. Paris. Retrieved September 15, 2014 from: http://download.eiie.org/Docs/WebDepot/20090705_EI-Statement-To-2nd-UNESCO-WCHE_en.pdf

UNICEF. (2000). Defining quality in education. A paper presented by UNICEF at the meeting of the international working group on education. Florence, Italy June 2000. Working Paper Series Education Section. New York: United Nations Children's Fund. Retrieved from http://www.unicef.org/education/files/QualityEducation.PDF. 